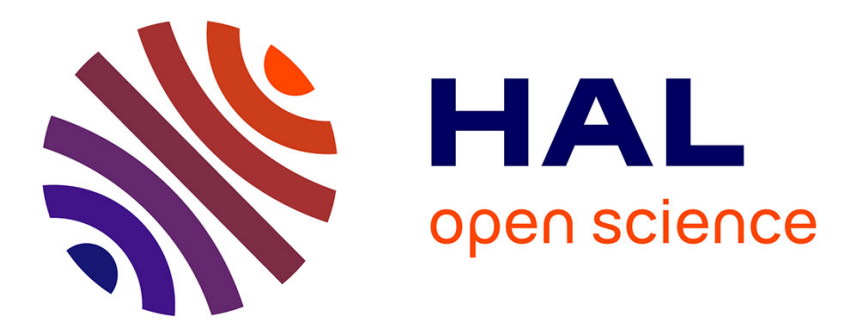

\title{
Macro and microplastics in stormwater and combined sewer overflows in Paris megacity
}

Robin Treilles, Johnny Gasperi, Saad Mohamed, Alain Rabier, Jérôme

Breton, Vincent Rocher, Sabrina Guerin, Bruno Tassin

\section{To cite this version:}

Robin Treilles, Johnny Gasperi, Saad Mohamed, Alain Rabier, Jérôme Breton, et al.. Macro and microplastics in stormwater and combined sewer overflows in Paris megacity. Novatech 2019, Jul 2019, Lyon, France. hal-02170901

\section{HAL Id: hal-02170901 \\ https://hal-enpc.archives-ouvertes.fr/hal-02170901}

Submitted on 2 Jul 2019

HAL is a multi-disciplinary open access archive for the deposit and dissemination of scientific research documents, whether they are published or not. The documents may come from teaching and research institutions in France or abroad, or from public or private research centers.
L'archive ouverte pluridisciplinaire HAL, est destinée au dépôt et à la diffusion de documents scientifiques de niveau recherche, publiés ou non, émanant des établissements d'enseignement et de recherche français ou étrangers, des laboratoires publics ou privés. 
